groups were almost always found, there were few differences between women with mild hypertension and the normotensive controls. This could have been because only severer degrees of hypertension modify the metabolic abnormalities already present in patients on the pill. Alternatively, as the normotensive group was matched with the whole hypertensive population rather than the subgroups with mild or severe hypertension, the mild subgroup was on average younger and therefore less overweight and less parous than the normotensive group. This could have influenced metabolic functions independently and thus masked a small adverse metabolic effect truly associated with mild hypertension.

The most striking feature of the study is the uniform pattern of progressive abnormalities seen as groups of patients are followed from Wynn and Doar's (1969) pre-pill group at one extreme to the severe hypertensives at the other. Without exception, the same pattern is seen for fasting serum lipids and for blood glucose and pyruvate both before and after glucose loading. This observation shows that the metabolic abnormalities seen in women who are hypertensive on combined oral contraceptives are qualitatively the same as those seen in women who are normotensive on the pill, and are therefore likely to be due to an exaggerated expression of these changes.

As in normotensive women, discontinuance of the preparation leads to progressive return of metabolic changes towards normal, though neither fasting plasma glucose, pyruvate, nor lipids, nor glucose area, had returned to normal at three months after stopping the pill. It is consistent with clinical experience that these metabolic functions, and also blood pressure, may take many months to come to pre-pill levels (Macintosh, 1968; Weinberger et al., 1969). This similarity between the time course of reversal of metabolic and blood pressure changes provides some further support for a common causation of the two effects.

The findings suggest that a number of different side effects of combined oral contraceptives may have a single biochemical basis, such as increased glucocorticoid activity. This leads to changes in blood pressure, weight, and metabolic functions which are statistically significant in large populations and clinically significant in particular individuals. The presence of clinically important abnormalities is determined both by the severity of the basic biochemical abnormality and by the presence of intrinsic predisposing factors. For metabolic abnormalities these may include genetic constitution, weight, age, and parity; while age, genetic factors, and previous toxaemia of pregnancy (Clezy et al., 1972) may be some of the factors acting in the case of blood pressure.
From the practical point of view, as both the hypertensive and metabolic effects of the pill may be atherogenic, older women of high weight and parity and those with a history of toxaemia of pregnancy should be supervised with particular care when given combined oral contraceptives.

We acknowledge the receipt of a grant from the Medical Research Council.

\section{References}

Adams, P. W., and Oakley, N. W. (1972). Clinics in Endocrinology and Metabolism, 1, 697.

Catt, K. J., et al. (1971). Lancet, 1, 459.

Clezy, T. M., Foy, B. N., Hodge, R. L., and Lumbers, E. R. (1972). British Heart Fournal, 34, 1238.

Cramp, D. G. (1967). Fournal of Clinical Pathology, 20, 910.

Cramp, D. G. (1968). Fournal of Clinical Pathology, 21, 171.

Cramp, D. G., and Robertson, G. (1968). Analytical Biochemistry, 25, 246.

Crane, M. G., and Harris, J. J. (1969. Fournal of Clinical Endocrinology and Metabolism, 29, 558 .

Dewhurst, C. J. (1972). Integrated Obstetrics and Gynaecology for Postgraduates, ed. C. J. Dewhurst, p. 269. Oxford, Blackwell Scientific.

Di Paola, G., Puchulu, F., Robin, M., Nicholson, R., and Marm, M. (1968). American fournal of Obstetrics and Gynecology, 101, 206.

Doar, J. W. H., and Wynn, V. (1970). British Medical fournal, 1, 149.

Drazin, M. L. (1953). Diabetes, 2, 433.

Harding, P, Oakley, N., and Wynn, V. (1973). Submitted for publication.

Hazzard, W. R., Spiger, M. J., Bagdade, J. D., and Bierman, E. L. (1969) New England fournal of Medicine, 280,471 .

Javier, Z., Gershberg, H., and Hulse, M. (1968). Metabolism, 17, 443.

Kunin, C. W. McCormack, R. C., and Abernathy, J. R. (1969). Archives of Internal Medicine, 123, 362.

Laragh, J. H. (1970). Circulation, 62, 983.

Macintosh, A. M. (1968). Medical fournal of Australia, 2, 1010.

Newton, M. A., Sealey, J. E., Ledingham, J. G. G., and Laragh, J. H. (1968). American fournal of Obstetrics and Gynecology, 101, 1037.

Pyke, D. A., and Please, N. W. (1957). Fournal of Endocrinology, 15, xxvi.

Robertson, G., and Cramp, D. G. (1970). Fournal of Clinical Pathology, 23, 243.

Saruta, T., Saade, G. A., and Kaplan, N. M. (1970). Archives of Internal Medicine, 126, 621 .

Skinner, S. L., Lumbers, E. R., and Symond, E. M. (1969). Clinical Science, 36, 67.

Spellacy, W. N., and Birk, S. A. (1972). American fournal of Obstetrics and Gynecology, 112, 912 .

Spellacy, W. N., Buhi, W. C., Spellacy, C. E., Moses, L. E., and Goldzieher, J. W. (1970). American fournal of Obstetrics and Gynecology, 106, 173. Stokes, T., and Wynn, V. (1971). Lancet, 2, 677.

Tyson, J. E. A. (1968). American fournal of Obstetrics and Gynecology, 100, 875.

Walters, W. A. W., and Lim, Y. L. (1969). Lancet, 2, 879.

Weinberger, M. H., Collins, R. D., Dowdy, A. J., Nokes, G. W., and Luetscher, J. A. (1969). Annals of Internal Medicine, 71, 891.

Weir, R. J., et al. (1971). Lancet, 1, 467.

Woods, J. W. (1967). Lancet, $2,653$.

Wynn, V., and Doar, J. W. H. (1969). Lancet, 2, 761 Wynn, V., and Doar, J. W. H. (1969). Lancet, $2,761$.
Wynn, V., Mills, G. L., Doar, J. W. H., and Stokes, T. (1969). Lancet, 2,

\title{
Prevalence of Tetracyclines in Children's Teeth- Study II: A Resurvey after Five Years
}

\author{
D. J. STEWART
}

British Medical fournal, 1973, 3, 320-322

\section{Summary}

The capacity of the tetracyclines to discolour teeth has been widely recognized for bver 10 years. This survey examined recent trends in tetracycline usage as shown Department of Child and Preventive Dentistry, The Queen's Uni-
versity, Belfast BT12 6BP

D. J. STEWART, M.D.S., F.F.D., Reader and Consultant by deposits of the antibiotic in primary molars extracted from 505 children aged from 3 to 5 years.

It was found that $\mathbf{7 0} \%$ of the children had been given the antibiotic during their first three years of life, each having received on average 2.4 courses. This represented an increase of $12 \%$ in tetracycline usage in children of this age as compared with a similar series five years ago. There was no evidence of increasing preference by prescribers for oxytetracycline (the analogue least likely to cause dental discoloration). Staining of the permanent incisor teeth frequently occurs if tetracyclines are given to children under 6 years of age and it is predicted that 
some degree of staining will occur in about $23 \%$ of the children in this series.

All things considered, there appears to be a strong case for stopping the manufacture of paediatric preparations of tetracycline except for those comprised of oxytetracycline for use in exceptional cases.

\section{Introduction}

In an earlier study (Study I) carried out in this area during 1966-7 (Stewart, 1968) it was shown that beginning about the mid-1950's the use of tetracyclines rapidly increased so that the number of children with deposits of this antibiotic in their teeth was much the greatest in the youngest age groups. The results also suggested that administration of these antibiotics to young children might still be increasing.

This study (Study II) examines recent trends.

\section{Materials and Method}

Second primary molars extracted because of caries were collected from children who were aged 3, 4, and 5 years between May 1971 and May 1972. After cleaning, the teeth were first examined in daylight for tetracycline discoloration of the crown, then sectioned longitudinally and the dentine examined with the aid of a hand lens in a darkroom under ultraviolet light.

Viewed in this way deposits of tetracycline were visible as fluorescent bands in the dentine. The number of teeth which had tetracycline and the number of its deposits was recorded, and, according to the donor's age and the location of the deposits, the year of their administration was calculated by reference to calcification tables. A separate note was kept of deposits judged by their colour to be of oxytetracycline.

\section{Results}

Second primary molars complete their development during the first three years of life, so that deposits of tetracycline incorporated in the dentine of these teeth are related solely to courses of the antibiotic administered during that period. In the present series of teeth from children aged from 3 to 5 years, therefore, all fluorescent deposits were related to courses of the drug given between May 1966 and May 1972 .

A total of 505 molars (one from each patient) was examined and of these $70 \%$ (354) were found to be tetracycline-positivethat is, to have at least one fluorescent deposit in the dentine. A degree of crown discoloration that would have been evident in vivo was seen in $19 \%$ (96)

Specimens were grouped according to donor's age, and table I shows the percentages of tetracycline-positive teeth found in each of the age groups examined, their year of birth, and the calendar years in which the antibiotic was administered.

The number of fluorescent deposits (which includes the number of deposits of oxytetracycline) found in the dentine of TABLE I-Percentage of Second Primary Molars from 505 Children aged from
3 to 5 Years Born between May 1966 and May 1969 Showing Deposits of 3 to 5 Years Born between May 1966 and May 1969 Showing Deposits of Tetracycline, and Percentage having Tetracycline Staining of Crown. All Years of Life

\begin{tabular}{|c|c|c|c|c|c|}
\hline $\begin{array}{c}\text { Age } \\
\text { Groups } \\
\text { (Years) }\end{array}$ & $\begin{array}{c}\text { Donor's } \\
\text { Year of } \\
\text { Birth } \\
\text { (May-May) }\end{array}$ & $\begin{array}{c}\text { Years } \\
\text { (May-May) } \\
\text { when } \\
\text { Tetracycline } \\
\text { was } \\
\text { Deposited }\end{array}$ & 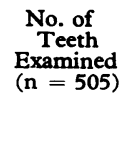 & $\begin{array}{c}\text { Teeth } \\
\text { Showing } \\
\text { Tetracycline } \\
\text { Deposits }\end{array}$ & $\begin{array}{l}\text { Teeth } \\
\text { Showing } \\
\text { Crown } \\
\text { Discolora- } \\
\text { tion }\end{array}$ \\
\hline $\begin{array}{cc}\text { Age } 3 & \ldots \\
\text { Age } 4 & \ldots \\
\text { Age } 5 & \ldots\end{array}$ & $\begin{array}{l}1968-9 \\
1967-8 \\
1966-7\end{array}$ & $\begin{array}{l}1968-72 \\
1967-71 \\
1966-70\end{array}$ & $\begin{array}{l}146 \\
211 \\
148\end{array}$ & $\begin{array}{r}(98) 67 \% \\
(151) 72 \% \\
(105) 71 \% \\
\end{array}$ & $\begin{array}{l}\text { (23) } 16 \% \\
\text { (43) } 20 \% \\
\text { (30) } 20 \%\end{array}$ \\
\hline \multicolumn{2}{|c|}{ Percentage of total } & .. & .. & $70 \%$ & $19 \%$ \\
\hline
\end{tabular}

the specimens in relation to the various age groups are given in table II. To allow direct comparisons to be made between groups, the findings are also expressed as the number of fluorescent deposits found per 100 teeth. Also included are separate details concerning the deposits of oxytetracycline.

TABLE II-Number of Deposits of Tetracycline (which includes Oxytetracycline) found in Second Primary Molars from 505 Children aged 3 to 5 years Born between May 1966 and May 1969

\begin{tabular}{|c|c|c|c|c|c|c|}
\hline $\begin{array}{l}\text { Age } \\
\text { Groups } \\
\text { (Years) }\end{array}$ & $\begin{array}{c}\text { Donor's } \\
\text { Year of } \\
\text { Birth } \\
\text { (May-May) }\end{array}$ & $\begin{array}{c}\text { No. of } \\
\text { Teeth } \\
\text { Examined } \\
(n=505)\end{array}$ & $\begin{array}{c}\text { No. of } \\
\text { Tetra- } \\
\text { cycline } \\
\text { Deposits } \\
(\mathrm{n}=1,231)\end{array}$ & $\begin{array}{c}\text { Tetra- } \\
\text { cycline } \\
\text { Deposits } \\
\text { per } \\
100 \text { Teeth }\end{array}$ & $\begin{array}{c}\text { No. of } \\
\text { Oxytetra- } \\
\text { cycline } \\
\text { Deposits }\end{array}$ & $\begin{array}{c}\text { Oxytetra- } \\
\text { cycline } \\
\text { Deposits } \\
\text { per } \\
100 \text { Teeth }\end{array}$ \\
\hline $\begin{array}{l}\text { Age } 3 \ldots \\
\text { Age } 4 \ldots \\
\text { Age } 5 \ldots\end{array}$ & $\begin{array}{l}1968-9 \\
1967-8 \\
1966-7\end{array}$ & $\begin{array}{l}146 \\
211 \\
148\end{array}$ & $\begin{array}{l}290 \\
558 \\
383\end{array}$ & $\begin{array}{l}199 \\
264 \\
258\end{array}$ & $\begin{array}{l}17 \\
38 \\
30\end{array}$ & $\begin{array}{l}12 \\
18 \\
20\end{array}$ \\
\hline \multicolumn{4}{|c|}{ Average No. of deposits per 100 teeth } & 240 & & \\
\hline
\end{tabular}

\section{Discussion}

Results of this survey show that compared with the continuing sharply rising trend found in Study I there has been over the past five years a distinct levelling off in the number of children per head of population given tetracycline during the first three years of life. In this study the prevalence of 67,72 , and $71 \%$ of tetracycline-positive teeth in the 3, 4, and 5 year old groups respectively, compared with 76,73 , and $67 \%$ in these similar age groups five years ago, is still disappointingly high.

Previously unpublished data concerning age groups 3 to 5 years from Study I is given in table III, and the number of courses of tetracycline given to children born between May 1961 and May 1964 during their first three years of life are shown. These data, combined with information from the present survey, are incorporated in the graph, which is constructed to show the trend in tetracycline administration to children during their first three years of life over the past decade (except for children born in the inter-study years May 1964 to May 1966 who were not surveyed).

TABLE III-Data taken from Survey Conducted in 1966-7 (Study I) Showing No. of Deposits of Tetracycline in 300 Second Primary Molars from Children aged from 3 to 5 Years Born between May 1961 and May 1964. All Deposits are Related to Tetracycline Given during their First Three Years of Life

\begin{tabular}{|c|c|c|c|c|c|}
\hline \multicolumn{2}{|c|}{$\underset{\text { Age Group }}{\text { (Years) }}$} & \multirow{2}{*}{$\begin{array}{c}\begin{array}{c}\text { Donor's Year } \\
\text { of Birth } \\
\text { (May-May) }\end{array} \\
1963-4 \\
1962-3 \\
1961-2\end{array}$} & \multirow{2}{*}{$\begin{array}{c}\begin{array}{c}\text { No. of } \\
\text { Teeth } \\
\text { Examined }\end{array} \\
79 \\
136 \\
85\end{array}$} & \multirow{2}{*}{$\begin{array}{c}\begin{array}{c}\text { No. of } \\
\text { Tetracycline } \\
\text { Deposits }\end{array} \\
205 \\
299 \\
141\end{array}$} & \multirow{2}{*}{$\begin{array}{c}\begin{array}{c}\text { Tetracycline } \\
\text { Deposits per } \\
100 \text { Teeth }\end{array} \\
260 \\
220 \\
166\end{array}$} \\
\hline $\begin{array}{l}\text { Age } 3 \\
\text { Age } 4 \\
\text { Age } 5\end{array}$ & $\begin{array}{l}. \\
\ddot{ }\end{array}$ & & & & \\
\hline
\end{tabular}

As shown in the graph, the number of children per head of the population given tetracycline during the first three years of life continued to rise to a peak of $76 \%$ of those born between May 1963 and May 1964. On the other hand, as measured by the number of fluorescent deposits in the dentine, the children who were given the largest amounts of tetracycline were those born between May 1963 and May 1968; the peak number of deposits, 264 deposits per 100 teeth, being found in the teeth of the children born in the year May 1967 to May 1968 .

The overall average of 240 tetracycline deposits per 100 teeth found in the combined groups of this series compared with 215 deposits per 100 teeth in Study I, amounts to an increase of $12 \%$ in the number of courses of these drugs issued to young children between May 1966 and May 1972 compared with children of similar age over a comparable period five years ago. 


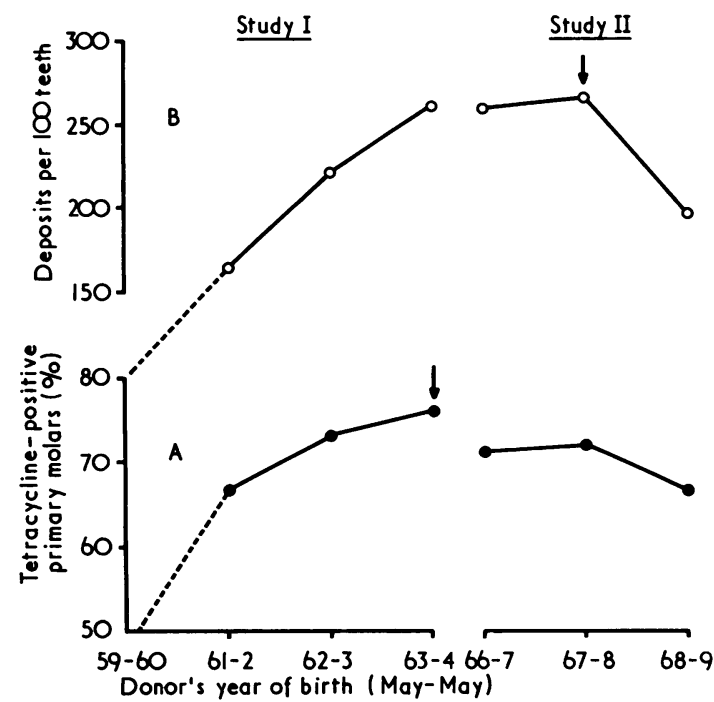

Graph constructed from combined information from present survey (Study II) and Study I (Stewart, 1968) to show trend of tetracycline administration to children born between May 1961 and May 1969 during first three years of life. A. Percentage of children, grouped according to year of birth, whose second primary molars had deposits of tetracycline. B. Number of tetracycline deposits per 100 teeth. Peak years are arrowed.

The fall in prevalence to $67 \%$ found here in the teeth of the youngest children born between May 1968 and May 1969 introduces a more hopeful note as it is the lowest level recorded for several years-that is, since the age 5 group born in the year May 1961 to May 1962 in Study I. This modest decline seems more significant when it is noted that the incidence of tetracycline deposits in this group of 199 deposits per 100 teeth amounts to a reduction of about $25 \%$ as compared with the levels found in any of the three preceding recorded years. Whether this decline marks the beginning of a lasting downward trend or is perhaps the reflection of such a passing influence as a succession of mild winters will have to await evidence from future investigations.

Crown Discoloration: Primary Teeth.-Tetracycline discoloration of the crown of primary teeth is related solely to dosages given up to the end of the first year of life-that is, during the period of primary crown development. The $19 \%$ of teeth in the present series with crown staining represents an increase of $4 \%$ above that found in the similar series five years ago.

Crown Discoloration: Permanent Teeth.-As stated above, all tetracycline deposits found in the second primary molars are related to dosages given during the first three years of life. These dosages therefore would also appear as deposits in the crowns of the teeth of the permanent series that mineralize concurrently. As noted previously (Stewart, 1968; Baker and Storey, 1970), the probability of discoloration occurring in permanent teeth that have tetracycline deposits in their crowns related to this period is about 1 in 3 . Using this information as a guide, and the fact that $70 \%$ of all the primary molars in this series were found to have tetracycline deposits, it can be estimated that about $23 \%$ of the children represented in this study will have some degree of discoloration of their permanent dentition.

Oxytetracycline.-Oxytetracycline has been noted by many observers as the type least likely to cause dental discoloration. Deposits of it in the dentine can usually be distinguished from those of other analogues by their creamy white colour, and many children who are given other forms of tetracycline would undoubtedly be spared dental disfigurement if oxytetracycline was used instead. However, as shown by the distribution of the deposits of this analogue (table II) there was no evidence in this survey to suggest that the use of it was increasing.

\section{Conclusions and Recommendations}

The unsightly effects that tetracyclines can have on the dentition has been widely known for over 10 years. Nevertheless this study shows that most of the child population still receives these drugs, and at an age when they are most likely to cause lasting discoloration of the permanent teeth.

The probability and degree of dental staining is influenced, inter alia, by the analogue of tetracycline used and the total amount given. However, if disfigurement of the permanent incisor teeth, which aesthetically are the most important, is to be avoided with certainty these drugs should never be given to children under the age of 6 years.

In view of the circumstances the high popularity still enjoyed by the tetracyclines is surprising. Current teaching makes it clear that indications for the use of these antibiotics in children are rare, other and more effective alternatives being available for the treatment of the commoner childhood infections for which the tetracyclines are still so often prescribed.

All things considered, there would seem to be a strong case for the manufacture of paediatric preparations of these antibiotics to be discontinued (Drug and Therapeutics Bulletin, 1967) except for those comprised of oxytetracycline for use in special cases.

Finally, Manten (1972) records that, because of dental disfigurement, the use of tetracyclines in some countries is loaded with medicolegal implications. This aspect of the problem should perhaps be brought more widely to the attention of prescribers in Britain.

\section{References}

Baker, K. L., and Storey, E. (1970). Medical fournal of Australia, 1, 109.

Drug and Therapeutics Bulletin, 1967, 5, 62. Stewart, D. J. (1968). British Dental fournal, 124, 318. 